\begin{tabular}{|c|c|c|}
\hline & Int.J.Curr.Microbiol.App.Sci (2021) 10(08): 471-493 & \\
\hline & $\begin{array}{l}\text { International Journal of Current Micro6iology and Applied Sciences } \\
\text { ISSN: 2319-7706 Volume } \mathbf{1 0} \text { Number } \mathbf{0 8}(\mathbf{2 0 2 1}) \\
\text { Journal homepage: http://www.ijcmas.com }\end{array}$ & $\begin{array}{l}50 \\
502\end{array}$ \\
\hline $\begin{array}{l}\text { EXCELLENT } \\
\text { PUBLISHERS }\end{array}$ & & whwe.jicmascom \\
\hline
\end{tabular}

\title{
Identification of Drought Tolerant among MARDI Rice Varieties based on Morpho-Agronomic Traits and Drought Grain Yield QTLS
}

\author{
Site Noorzuraini Binti Abd Rahman ${ }^{1 *}$, Mohd Shahril Firdaus Bin Abd Razak², \\ Norlida Mohamed Hamim², Mohd Ramdzan Bin Othman ${ }^{1}$ and \\ Nur Idayu Binti Abd Rahim ${ }^{1}$
}
${ }^{1}$ MARDI Seberang Perai, Jalan Paya Keladi, 13200 Kepala Batas, Pulau Pinang, Malaysia
${ }^{2}$ Ibu Pejabat MARDI, Persiaran MARDI-UPM, 43400 Serdang, Selangor, Malaysia
*Corresponding author

\section{A B S T R A C T}

\begin{tabular}{|l|}
\hline K e y w o r d s \\
$\begin{array}{l}\text { Rice, morpho- } \\
\text { agronomic traits, } \\
\text { drought grain yield } \\
\text { QTLs, drought } \\
\text { tolerant }\end{array}$ \\
\hline Article Info \\
\hline $\begin{array}{l}\text { Accepted: } \\
\text { 20 July 2021 } \\
\text { Available Online: } \\
\text { 10 August } 2021\end{array}$ \\
\hline
\end{tabular}

The development of drought tolerant rice varieties in Malaysia is slow due to limited number of available donors for breeding program. Evaluation of the genetic resources is crucial to increase availability of the potential drought tolerant donors. This study revealed MR219, MR220, MR253, MR269, MRQ74, MRQ76, SIRAJ297, MARDI284, SEMPADAN303, SEBERNAS307 and MARDI308 showed outstanding performance under drought stress based on tiller number, panicle length, harvest index, $\%$ of filled grain and grain yield. The least square means of grain yield showed MR269 was the highest followed with MRQ76, with grain yield reduction difference between the two environments was $46.84 \%$ and $54.44 \%$, respectively. The genotypic study observed three MARDI varieties which has more than one QTLs, namely MRQ74 ( $q D T Y_{3.2}$ and $\left.q D T Y_{11.1}\right)$, MR253 ( $q D T Y_{2.3}$ and $\left.q D T Y_{3.2}\right)$ and MRQ76 ( $q D T Y_{3.2}$, $q D T Y_{2.3}$ and $\left.q D T Y_{11.1}\right)$. The dendrogram based on morpho-agronomic traits observed MARDI284, MR269, MRQ746, MR253 and MRQ74 showed similarity with Dular. The dendrogram based on genotypic traits observed MRQ74 and MRQ76 showed similarity with Moroberekan. MRQ76 was identified as a potential drought tolerant variety as showed outstanding performance under drought stress and possessed three different QTLs namely $q D T Y_{3.2}, q D T Y_{2.3}$, and $q D T Y_{11.1}$.

\section{Introduction}

Rice (Oryza sativa) is the foremost staple food and fulfill the nutritional requirement of about 30 million people in Malaysia. The rice production in Malaysia is mainly from rice granary areas with average production per hectare was $4.47 \mathrm{mt} / \mathrm{ha}$ (Radin Firdaus et al.,
2020). To date, there are 10 major rice granary areas with additions of 74 secondary granaries and 172 minor granaries (Siti Rahyla et al., 2019). These granary areas are facilitated with well-developed farming system to fulfill the water requirements in the areas. Since, Malaysia is considered as a 'wet' continent as receives a rainfall at 250 centimeters a year 
(Saw 2007), it is seemly shows that Malaysia is less affected with drought incidences. However, shifting in rainfall pattern during dry season and increased of earth's temperature demonstrated that Malaysia has begun experienced significant effects on climate change (Marshall 2007). The annual report of Malaysian Meteorological Department reported the warmest year was in year 2016due to severe El Niño phenomenon. Whereas, 2019 was reported as the second warmest year in the last ten years (Malaysian Meteorology Department. 2019).

Among the rice granary areas, Kemubu Agricultural Development Authority (KADA) and Muda Agricultural Development Authority (MADA) were the most facing unpredictable droughts along the planting season (Khalijah et al., 2015). It has been reported that about 6 to $17 \%$ of the areas were affected by droughts from 2003 to 2012, which the highest incidences occurred in KADA(Khalijah et al., 2015). Whereas, the earliest severe drought in MADA happened in year 1998 that caused RM 159.5 million losses to the rice industry (Ahmad Jamalludin and Low, 2003).

Nowadays, droughts become the major natural disasters in Malaysia. It contributes to high reductions on productivity of agriculture commodities mainly rice (Hasegawa 2009). Rosenzweig et al., (1994) has stated that climate change in Malaysia affects the rice production as about 12 to $22 \%$ yield reduction. The previous study indicated that a global increase in temperature of $1^{\circ} \mathrm{C}$ can lead to yield reduction by $0.0308 \%$ in rice production (Khalijah et al., 2015).

The serious yield reduction observed in rice plant as it is most susceptible to drought compared to other cereal crops i.e., wheat and maize, which they were showed better adaptation under less water condition.
Moreover, the previous studies also discovered that rice are commonly affected to drought during reproductive stage that consequently cause serious effect on yield production (O'Toole 1982; Venuprasad et al., 2007; Kumar et al., 2014). Drought occurred prior to flowering time generally delayed the flowering time, decrease percentage of fertile panicle, and decrease percentage of filled grain (Pantuwan et al., 2002).

According to Babu et al., (2003), Lanceras et al., (2004), and Gomez et al., (2006) there were several considerations in identifying suitable donors for development of drought tolerant rice variety i.e., (i) selection of donors based on secondary traits that contribute to drought tolerant. There were many reported studies on usage of secondary traits for improving yield production under water limiting conditions, such as in maize (Ribaut et al., 2004), wheat (Condon et al., 2004) and sorghum (Sanchez 2002).Moreover, other secondary traits namely root architecture, relative water content, leaf water potential, canopy temperature, panicle exertion, leaf death and rolling had been used in identifying drought tolerant rice (Kumar 2018). As stated by Gomez et al., (2006), the ideal secondary traits were easier to measure, genetically correlated with grain yield under stress, highly heritable and showed high genetic variation in the targeted species.

Another consideration was (ii) identification of quantitative trait loci (QTL). Gomez et al., (2006) stated that the identification of genomiclocations linked to traits of interest and indirect selection can be done without the need of difficult phenotypic measurements. QTLs had been recognized with large and consistent effects on yield under drought stress (Venuprasad et al., 2011) and had been detected in several drought tolerant component traits in rice ( $\mathrm{Li}$ et al., 2005; Kamoshita et al., 2008; Swamy et al., 2011; 
Fen et al., 2015). According to Gomez et al., (2006) Even though the drought resistance traits can be detected by the locations of QTLs, however, there was still a requirement to monitor and determine the performance of the QTLs on drought grain yield under field conditions.

Currently the progress for development of drought tolerant rice variety in Malaysia is slow due to limited number of suitable donors for breeding program. To overcome this problem, there is a need to explore the available modern rice varieties and introduced as potential donors for future breeding program in MARDI. Thus, this study was conducted with specific objectives:

To evaluate the performance of fourteen MARDI rice varieties based morphoagronomic traits under drought stress environment

To assess the genetic diversity of fourteen MARDI rice varieties based on fourteen Simple Sequence Repeat (SSR) markers linked to drought grain yield QTLs; and

To identify the drought tolerant variety among the fourteen MARDI rice varieties as potential donor variety for development the drought tolerant rice variety

\section{Materials and Methods}

\section{Morphological Characterization under Drought Environment}

\section{Plant materials for drought stress study}

Fourteen MARDI rice varieties were selected based on popularity among the farmers and newly released by MARDI (Table 1). The varieties were derived through breeding program by MARDI rice breeders. In addition, two introduced varieties reportedly tolerant to drought and possess drought grain yield QTLs were also used in this study as tolerant control varieties, namely Moroberekan and Dular. Whereas, IR64, was used as sensitive control variety.

\section{Experimental and planting design}

The experiment was conducted under glasshouse condition at MARDI Seberang Perai, located at the Northern part of Peninsular Malaysia. Completely Randomized Design (Gomez and Gomez 1984) was used for laying out the experiment which consisted of two replications with ten plants of each variety for both drought and control environments. Each variety was arranged randomly to allow the varieties to receive the sunlight equally. Spacing between the rows was $15.0 \mathrm{~cm}$ and between varieties was 20.0 $\mathrm{cm}$.

\section{Drought stress imposition}

The fourteen MARDI rice varieties including two tolerant control varieties and one susceptible control variety were evaluated under drought and control environments. The seeds were sown in fiberglass troughs and transplanted into cement troughs at 20 days after sowing (DAS). Under control environment (non-stress), the cement troughs were surface flooded with standing water to a depth about $5.0 \mathrm{~cm}$ throughout the crop growth. Whereas, under drought stress environment, the seedlings were irrigated normally after transplanting, and thereafter drought stress was imposed by draining out water starting at late vegetative growth stage until maturity. Small canals (from the top of the soil until the bottom of the cement trough) were dug at the corner of the cement troughs for measuring the water table depth. Perforated PVC pipes were placed into the canals. The water table depth was measured daily until the water in the cement troughs 
totally dried. Surface irrigation was applied when most of the lines wilted and exhibited leaf drying. The irrigation is important to prevent the plants from dying during the experiment (Venuprasad et al., 2007). At reproductive stage stress period, soil moisture content was gravimetrically determined on an oven dry basis. The soil samples were collected twice i.e., on $26^{\text {th }}$ and $33^{\text {rd }}$ days after water suspension. At each sampling time, duplicate samples were taken to a depth of $60.0 \mathrm{~cm}$ using an auger. The samples were immediately transferred into tightly closed aluminium cans and weighed, oven-dried at $105^{\circ} \mathrm{C}$ for $24 \mathrm{~h}$, and reweighed after the moisture content was determined (Abd Allah et al., 2010).

\section{Morpho-agronomic characterization under drought environment}

The morpho-agronomic characterization was carried when most of rice plants having the panicles. There are several morpho-agronomic traits were selected to be recorded namely leaf length (LL) = length of the topmost leaf blade below the flag leaf on the main culm second leaf, leaf width $(\mathrm{LW})=$ width of the widest portion of the blade on the leaf below the flag leaf on the main culm, flag leaf length (FLL) = length of the flag leaf from the ligule to the tip of the blade, flag leaf width $($ FLW $)=$ width at the widest portion of the blade on the flag leaf; tiller number $(\mathrm{TN})=$ the total number of grainbearing and non-bearing tillers of each individual plant, culm length $(\mathrm{CL})=$ the distance from the ground to the tip of the panicle on the main tiller at maturity, culm diameter $(C D)=$ the diameter at the third internode of the stem after stripping off leaves and leaf sheaths, by using digital vernier caliper; panicle length $(\mathrm{PL})=$ length of main axis of panicle measured from the panicle base to the tip, grain yield $(\mathrm{GY})=$ the total filled grains weight from three plants, harvest index $(\mathrm{HI})=$ the grain, above ground biomass $(\mathrm{BM})$
= total weight of empty grains, stalk and straw weight in grams; percent of filled grain $(\mathrm{FG})=$ percentage of filled grain per plant, and maturity days (MAT) = the duration in days from seeding to the time when more than $90 \%$ of the grains on the panicles were fully ripened.

\section{Statistical analysis for phenotypic (morpho- agronomic) data}

The morphological characterization under drought and control environments were analyzed using Statistical Analysis System (SAS 9.3) to determine the mean, means square and $\mathrm{F}$ value. The significance levels were verified from the $\mathrm{F}$ values at $5 \%$ and $1 \%$ confident levels. The performance of the varieties under drought and control environments was measured with least means square and means comparison using SAS 9.3. The dendrogram for cluster analysis was performed using Multi-variate Statistical Package (MVSP).

\section{Molecular Analysis for Drought Grain Yield QTLs}

\section{Plant material and DNA extraction}

Leaf samples of each MARDI rice varieties including control varieties were collected and dried using silica gel prior to storage in freezer at $-20{ }^{\circ} \mathrm{C}$. Then for DNA extraction, the leaf samples were placed onto plate containing stainless steel bead $(5 \mathrm{~mm}$ in diameter) and immediately frozen at $-80{ }^{0} \mathrm{C}$ for at least 24 hours. The DNA was extracted following the protocol of Mace et al., (2003) with some modification in term of using semi-robotic equipment for high throughput DNA extraction. The frozen tissue was ground using Tissue Lyser (Qiagen, Germany) and immediately the Extraction buffer was added. The DNA integrity and concentration were measured using $0.8 \%$ agarose gels and 
Fluoraskan Ascent (Thermo Fisher Scientific, United States), respectively.

\section{SSR genotyping}

A total of 14 SSR markers which linked to $q D T Y_{3.2}, \quad q D T Y_{6.1}, \quad q D T Y_{11.1}, \quad q D T Y_{2.3}$ and $q D T Y_{12.1}$ were determined from GRAMENE based on relative position reported by Dixit et al., (2014) and Kumar et al., (2014) (Table 2). The PCR reaction was conducted following the protocol by Schuelke (2000) by ligating the primers (either forward or reverse) with a non-fluorescent labeled M13 sequence tail (TGTAAAACGACGGCCAGT). Sequence adapter will be complimentary and ligated with fluorescent label M13 sequence adapter (FAM, NED, PET, or VIC). The PCR reaction was performed with a final volume of $10 \mu \mathrm{L}$, and contained $1 \mathrm{x}$ buffer (Invitrogen, United States), $10 \mu \mathrm{M}$ each of forward and reverse primer, $5 \mu \mathrm{M}$ fluorescence-labeled M13 primer, $2 \mu \mathrm{M}$ of each dNTP (Invitrogen, United States) and $1 \mathrm{U}$ of Taq polymerase (Invitrogen, United States). Target sequence amplification was done using GeneAmp ${ }^{\circledR}$ PCR System 9700 (Applied Biosystems, United States). The PCR profile was set with initial denaturation at $94^{\circ} \mathrm{C}$ for $2 \mathrm{~min}$, followed by 36 cycles of $94{ }^{\circ} \mathrm{C}$ for $30 \mathrm{sec}, 41-65^{\circ} \mathrm{C}$ for 45 sec, and $72{ }^{\circ} \mathrm{C}$ for $45 \mathrm{sec}$, followed by final extension at $72{ }^{\circ} \mathrm{C}$ for $7 \mathrm{~min}$. The PCR product was multiplexed after the amplification was done and was multiplexed up to four different fluorescent dyes. Then, the PCR products were resolved using ABI 3730 xl using GeneScan 500 LIZ as a standard ladder.

\section{Statistical analysis for genotypic data}

The raw data generated by ABI 3730 xl were scored using GeneMapper Version 5 (Thermo Fisher Scientific, United States) in order to determine the allele size. The allele calls or peaks were scored following the suggestion by
Arif et al., (2010). The allele size of each marker was formatted in Excel before using them as input in Power Marker program (Liu and Muse 2005). The software was used to measure major allele frequency, number of alleles, heterozygosity, gene diversity and Polymorphism Information Content (PIC) of each SSR marker. The pair wise shared-allele genetic-distance base was calculated using the same software. MEGA7 (Kumar et al., 2016) was used to generate dendrogram based on the Unweighted Pair Group Method with Arithmetic Mean (UPGMA) which was constructed using generated pair wise genetic distance.

\section{Identification of rice accessions tolerant to drought stress}

Strategy for selecting the promising MARDI rice variety for drought stress was determined using two dendrograms constructed based on Pearson's Correlation Coefficient using phenotypic (morpho-agronomic traits) and genotypic data (SSR markers linked to drought grain yield QTLs). The varieties which were grouped in the same cluster with tolerant control varieties in both dendrograms were considered having genetic similarities. Furthermore, the growth performance of each rice variety in the group were assessed based on the grain yield and yield related traits under drought environment. Thus, the MARDI rice variety which was grouped together with tolerant control varieties and exhibited promising growth performance under drought environment was considered as a potential MARDI rice variety for drought tolerance.

\section{Results and Discussion}

\section{Drought imposition under drought stress environment}

The fourteen MARDI rice varieties and three control varieties were evaluated under drought 
and normal environments. Drought stress was imposed by draining out the standing water at late vegetative stage (40 DAS). The drought was imposed at late vegetative stage to guarantee the plants be in state of drought stress condition before they reached the flowering stage. Similarly, Pantuwan et al., (2002) conducted drought stress at booting stage to allow the rice plants experienced water deficit around the second week of flowering until maturity stage. The previous studies reported the effect of drought stress in rice at flowering stage, which were on yield and yield components (Abd Allah et al., 2010); grain number per panicle (Boonjung 1996); dry matter production; and filled grain (Abd Allah et al., 2010).

The study reached drought stress condition when the water table depths howed zero reading and soil moisture achieved below $10 \%$. Water table depth reached zero reading on $5^{\text {th }}$ days of drought imposition (Figure 1).While, soil moisture reached $10 \%$ at $26^{\text {th }}$ days and below $10 \%$ at $33^{\text {rd }}$ days of drought imposition(Figure 2). This study confirmed that the MARDI rice varieties were exposed to moderate and severe drought stress along the experiment (Picture 1). The sensitive control variety started to exhibit drought stress symptoms at $30^{\text {th }}$ days of drought stress. Similarly, Zu et al., (2017) also observed the top three leaves of the sensitive cultivars were tightly rolled, wilted, and drying at $10 \%$ moisture content.

Variation in morpho-agronomic traits under drought environment

The analysis onmorpho-agronomic traits under both drought and normal environments were analysed using ANOVA test (Table 3). There was a significant difference for all studied straits for variety and treatment (except for LW); whereas several traits namely CL, MAT, $\mathrm{HI}$ and GY showed significant difference for
Var*Trt (Table 4). Table 3 showed significant difference for all studied traits under both environments, with the highly significant difference observed in LL, LW, FLL, FLW, TN, CL, BM, and MAT (Table 3). Dular as one of the drought tolerant control variety showed the highest mean value of LL, CL, and CD (Table 4). Whereas, Moroberekan is another drought tolerant control variety also showed highest mean value under drought for LW and FLW. There were four varieties exhibited more TN under drought environment compared to control varieties, namely MRQ74, MARDI284, SIRAJ297, and SEBERNAS307. The highest TN was observed in MRQ74 with the mean value of 6.70. Meanwhile, the longest PL was observed in SEBERNAS307 with the mean value of 24.00. Other MARDI varieties that also showed longer PL compared to the control varieties under drought environment are MARDI308, MR219 and SEMPADAN303.

Meanwhile, the highest mean value of BM observed in SEBERNAS307, whereas the highest mean value of HI observed in MR219; MR253; and MARDI308 with the value is 0.30 . Dular showed the highest mean value of FG with the value is 61.18. Whereas the second highest of FG observed in MRQ74 followed with MRQ76. Mean value of GY observed MR269 showed the highest with the value is 4.20 followed with MRQ76 with the value is 4.06. The mean value of $\mathrm{HI}$ in MARDI rice varieties was higher than Dular and Moroberekan. Dular exhibited highest HI compared to the other control varieties, produced the highest GY with a value of 2.89 g. Similarly, MR219 and MARDI308 also showed higher HI among the MARDI rice varieties which produced higher GY with the value of $3.47 \mathrm{~g}$ and $3.55 \mathrm{~g}$, respectively.

However, the highest GY was observed in MR269 followed by MRQ76 with the value of $4.20 \mathrm{~g}$ and $4.06 \mathrm{~g}$, respectively. 
In overall, the mean value under drought environment observed eleven MARDI rice varieties showed outstanding performance under drought stress environment compared to the tolerant control varieties based on GY and yield related traits, namely, TN, PL, HI, and FG. The varieties are MR219, MR220, MR253, MR269, MRQ74, MRQ76, SIRAJ 297, MARDI284, MARDI308, SEMPADAN303, and SEBERNAS307.

\section{Grain yield performance under drought environment}

The performance of studied traits was compared based on mean between the two environments using Duncan Multiple Range Test (Table 5). All the studied traits showed reduction under drought environment. The highest percentage of reduction observed in GY with the percentage is $60.92 \%$. HI showed about half percent reduction under drought environment with the value is $48.89 \%$, whereas FG showed reduction at $39.51 \%$ under drought environment. Five MARDI rice varieties showed higher GY under drought environment and no significant difference with drought tolerant variety, Dular, the varieties were MARDI284, MRQ76, MR232, MR220, and MR269 (Figure 3). Among the varieties, MARDI284 produced the highest grain yield, followed by MRQ76.

Least square means of the GY under drought stress and normal environments was presented in Figure 4. This study observed the control varieties and all MARDI rice varieties showed reduction in GY under drought compared to normal environment. MR269 showed the highest least square means on GY under drought environment with the value is 4.2 ; followed by MRQ76 with the value is 4.1. MRQ74 showed the minimum percentage of GY reduction between the two environments with the percentage value is $10.0 \%$. While, MR269 that showed the highest least square means on GY under drought environment; exhibited $46.84 \%$ of yield reduction difference. Whereas, MRQ76 was the second highest of least square means on GY under drought environment showed $54.44 \%$ of yield reduction difference. Meanwhile, the tolerant control variety, Dular showed the higher GY reduction compared to MR269 which was $67.05 \%$. This study observed MR269 and MRQ76 exhibited outstanding performance in HI, GY under drought environment and also presented less grain reduction difference compared to the control varieties.

The negative effects of drought on rice traits especially on grain yield was also observed in many previous studies (Fukai and Cooper 1995; Pantuwan et al., 2002; Site Noorzuraini et al., 2012). Kumar et al., (2015) observed the rice yield reduction difference between drought stress and non-stress ranged from $27.31 \%$ to $67.7 \%$. Abarshahr et al., (2011) stated that the increased and decreased of GY was actually due to the potential of yield related traits in the variety itself and the different responses to environmental factors. Whereas, Abd Allah et al., (2010) stated the impact of drought stress upon grain yields due to reduction of productive tillers and reduction of grain number per panicle. Moreover, the outstanding traits related to grain yield under drought stress were superiority in tiller number, panicle number, low sterility and heavier in grain weight (Abd Allah et al., 2010). Thus, varieties that showed prominent traits on GY and yield related traits in this study may considered as promising varieties for future breeding program in MARDI.

\section{Genetic diversity among MARDI rice varieties}

In this study, fourteen simple sequence repeat (SSR) markers were used to determine the major allele frequency, allele number, allele diversity, heterozygosity and Polymorphic 
Information Content (PIC) values among the MARDI rice varieties (Table 7). The results showed 41 reproducible alleles were amplified with an average of 4.56 alleles per locus. The number of the alleles varied from 2 to 8 alleles per locus. A total of $6.1 \%$ of major alleles frequency were observed. Previous study reported 84 alleles per locus in 7 rice genotypes with an average of 2.89 alleles per locus (Roy et al., 2015). Similarly, Singh et al., (2016) detected 63 alleles with an average of 2.75 alleles per locus. The highest mean major allele frequency was observed in chromosome 3 with the value of $0.83 \%$, while the lowest was observed in chromosome 2 and 6 with the value of 0.51 . The average gene diversity over all SSR loci was 0.46 , with the highest at chromosome 2 with the value of 0.67 .

PIC value is a reflection of allele frequency and allele diversity which provides discriminating power of a marker locus in a given population. PIC values varied from 0.096 (RM3894) to 0.706 (RM204) with the average of 0.43 . The highest mean PIC value was observed in chromosome 2 with the value of 0.628. and the lowest was observed in chromosome 3 with the value of 0.271 . About $57.1 \%$ of the markers showed higher PIC values (>0.50), namely, RM530, RM14291, RM204, RM209, and RM7391. Higher PIC values indicated that the markers were highly informative, suitable for detecting more alleles and useful for distinguishing the polymorphic rate of the markers at a specific locus (DeWoody et al., 1995). Previous studies observed higher PIC values (>0.50) in various rice backgrounds such as cultivars, landraces and wild relatives (Ravi et al., 2003; Ram et al., 2007; Site Noorzuraini et al., 2013). Among the highest PIC values observed were 0.97 in 100 high yielding rice genotypes
(Choudhary et al., 2013); 0.93 in seven aromatic rice varieties (Roy et al., 2016); and 0.95 in medicinal rice (Behera et al., 2012); and 0.75 in 192 diverse rice genotypes (Nachimuthu et al., 2015).

\section{Drought grain yield QTLs in MARDI rice varieties}

Previous studies had discovered several largeeffect QTLs on grain yield under reproductive stage drought for both upland and lowland rice conditions(Bernier et al., 2007; Kumar et al., 2007; Venuprasad et al., 2009; Vikram et al., 2011; Ghimire et al., 2012; Venuprasad et al., 2012; Mishra et al., 2013; Yadaw et al., 2013; Kumar et al., 2014; Vikram et al., 2016).

Bernier et al., (2007) reported the first largeeffect QTL of $q D T Y_{12.1}$ for grain yield under reproductive stage drought. The identified QTL is important as an ultimate used in marker-assisted backcross breeding approach and QTL introgression in popular rice varieties (Kumar et al., 2014).

In this study, three QTLs were determined and linked to the selected markers, namely, $q D T Y_{3.2}$ (Vikram et al., 2011); $q D T Y_{11.2}$; and $q D T Y_{2.3}$ (Palanong et al., 2014) The highest frequency of QTL was observed in $q D T Y_{3.2}$, the donor variety for this QTL is Moroberekan(Figure 5). There were seven MARDI rice varieties that possessed this QTL namely MR219, MR220, MR253, MR269, MRQ74, MRQ76, and MARDI284. $q D T Y_{3.2}$ is one of the known Mega-QTLs (MQTL) and one of the large effect QTLs was identified as the most precise and consistent across the environments and useful for Marker-assisted Selection (MAS), candidate gene identification and functional analysis (Swamy et al., 2011; Kumar et al., 2014). 
Table.1 List of MARDI rice varieties and control varieties for drought stress study

\begin{tabular}{|c|c|c|c|c|c|}
\hline No. & Variety Name & $\begin{array}{c}\text { Accession } \\
\text { Number }\end{array}$ & No. & Variety Name & $\begin{array}{c}\text { Accession } \\
\text { Number }\end{array}$ \\
\hline $\mathbf{1}$ & Moroberekan & MRGB10930 & 10 & MRQ76 & MRGB12109 \\
\hline $\mathbf{2}$ & Dular & MRGB10735 & 11 & MR269 & MRGB12120 \\
\hline $\mathbf{3}$ & IR64 & MRGB10808 & 12 & MARDI 284 & MRGB12140 \\
\hline $\mathbf{4}$ & MR219 & MRGB11633 & 13 & MARDI SIRAJ 297 & MRGB13019 \\
\hline $\mathbf{5}$ & MR220 & MRGB11634 & 14 & MARDI WANGI 88 & MRGB13020 \\
\hline $\mathbf{6}$ & MRQ74 & MRGB11787 & 15 & SEMPADAN303 & MRGB13001 \\
\hline $\mathbf{7}$ & MR232 & MRGB12047 & 16 & SEMPADAN307 & MRGB13005 \\
\hline $\mathbf{8}$ & MR253 & MRGB12095 & 17 & MARDI 308 & MRGB13006 \\
\hline $\mathbf{9}$ & MR263 & MRGB12133 & & & \\
\hline
\end{tabular}

Table.2 List of 14 specific SSR markers linked to the respective drought grain yield QTLs and the drought tolerant check varieties

\begin{tabular}{|c|c|c|}
\hline Chromosome No. & QTLs & SSR Markers \\
\hline $\mathbf{3}$ & $q D T Y_{3.2}$ & RM14291, RM3894, RM6013 \\
\hline $\mathbf{6}$ & $q D T Y_{6.1}$ & RM204, RM19367, RM549, \\
\hline $\mathbf{1 1}$ & $q D T Y_{11.1}$ & RM3625, RM7391, RM209 \\
\hline $\mathbf{2}$ & $q D T Y_{2.3}$ & RM530 \\
\hline $\mathbf{1 2}$ & $q D T Y_{12.1}$ & RM573, RM1261, RM28099, RM28166 \\
\hline
\end{tabular}


Table.3 The mean, standard deviation, variance, coefficient of variation, mean square, F value, and $\mathrm{Pr}>\mathrm{F}$ of all studied traits under drought and normal environments

\begin{tabular}{|c|c|c|c|c|c|c|c|c|c|}
\hline Variable & $\mathbf{N}$ & Mean & Minimum & $\begin{array}{c}\text { Maximu } \\
\mathbf{m}\end{array}$ & Std Dev & $\begin{array}{c}\text { Coeff of } \\
\text { Variation }\end{array}$ & $\begin{array}{c}\text { Mean } \\
\text { Square }\end{array}$ & F Value & Pr $>$ F \\
\hline Leaf length (LL) & 68 & 43.60 & 26.44 & 68.10 & 8.54 & 12.91 & 167.93 & 5.30 & $<.0001$ \\
\hline Leaf width (LW) & 68 & 13.09 & 10.40 & 19.33 & 1.56 & 6.61 & 7.20 & 9.64 & $<.0001$ \\
\hline $\begin{array}{c}\text { Flag leaf length } \\
\text { (FLL) }\end{array}$ & 68 & 30.10 & 17.72 & 50.40 & 6.69 & 14.96 & 114.87 & 5.66 & $<.0001$ \\
\hline $\begin{array}{c}\text { Flag leaf width } \\
\text { (FLW) }\end{array}$ & 68 & 14.48 & 11.00 & 20.67 & 1.82 & 5.77 & 8.09 & 11.56 & $<.0001$ \\
\hline Culm length (CL) & 68 & 60.80 & 32.80 & 99.33 & 14.93 & 7.36 & 320.75 & 16.03 & $<.0001$ \\
\hline Tiller number (TN) & 68 & 4.26 & 2.00 & 7.60 & 1.30 & 16.99 & 3.34 & 6.40 \\
\hline Culm diameter(CD) & 68 & 3.15 & 1.63 & 4.50 & 0.61 & 15.79 & 0.66 & 2.65 \\
\hline Panicle length (PL) & 68 & 23.14 & 14.60 & 31.33 & 4.01 & 8.62 & 17.35 & 4.36 \\
\hline Maturity (MAT) & 68 & 126.62 & 97.00 & 145.00 & 13.70 & 2.74 & 131.47 & 10.93 \\
\hline Biomass (BM) & 67 & 13.69 & 5.22 & 25.80 & 4.71 & 20.24 & 46.93 & 6.11 \\
\hline Harvest Index (HI) & 67 & 0.34 & 0.08 & 0.59 & 0.13 & 17.10 & 0.01 & $<.0001$ \\
\hline Filled Grain (FG) & 67 & 60.06 & 23.65 & 92.91 & 19.22 & 16.84 & 224.44 & 2.12 \\
\hline Grain yield (GY) & 67 & 4.99 & 0.48 & 14.03 & 3.07 & 27.89 & 8.08 & 4.0001 \\
\hline
\end{tabular}


Table.4 Statistical analysis for variety, replicate, treatment, variety*treatment for all studied traits

\begin{tabular}{|c|c|c|c|c|c|c|c|}
\hline Source & Leaf Length & Leaf Width & $\begin{array}{c}\text { Flag Leaf } \\
\text { Length }\end{array}$ & $\begin{array}{c}\text { Flag Leaf } \\
\text { Width }\end{array}$ & Culm Length & $\begin{array}{c}\text { Culm No. } \\
\text { Diameter }\end{array}$ \\
\hline Variety & $<.0001^{* *}$ & $<.0001^{* *}$ & $<.0001^{* *}$ & $<.0001^{* *}$ & $<.0001^{* *}$ & $<.0001 * *$ & $0.0088^{* *}$ \\
\hline Replicate & 0.9244 & 0.2873 & 0.8304 & 0.9163 & $0.0041^{* *}$ & 0.3966 & 0.667 \\
\hline Treatment & $<.0001 * *$ & 0.1433 & $0.001 * *$ & $<.0001 * *$ & $<.0001 * *$ & $<.0001 * *$ & $0.0051^{* *}$ \\
\hline Var*Trt & 0.9158 & 0.0771 & 0.7817 & 0.0845 & $0.0236^{*}$ & 0.5613 & 0.4417 \\
\hline
\end{tabular}

Table.4 Cont.

\begin{tabular}{|c|c|c|c|c|c|c|}
\hline Source & Panicle Length & Maturity & Biomass & Harvest Index & \% Filled Grain & Grain Yield (g) \\
\hline Variety & $0.0002^{* *}$ & $<.0001^{* *}$ & $<.0001^{* *}$ & $0.0346^{*}$ & $0.0286^{*}$ & $0.0003^{* *}$ \\
\hline Replicate & 0.8352 & 0.1515 & $0.0186^{*}$ & $0.0205^{*}$ & 0.7162 & $0.003^{* *}$ \\
\hline Treatment & $<.0001 * *$ & $<.0001^{* *}$ & $<.0001 * *$ & $<.0001^{* *}$ & $<.0001^{* *}$ & $<.0001 * *$ \\
\hline Var*Trt & 0.5567 & $0.0062^{* *}$ & 0.1916 & $0.0154^{*}$ & 0.0791 & $0.0034^{* *}$ \\
\hline
\end{tabular}


Table.5 Mean values of the secondary traits, phenotypic traits, and integrative traits of fourteen MARDI varieties and control varieties under drought stress

\begin{tabular}{|c|c|c|c|c|c|c|c|c|c|c|c|c|c|}
\hline Variety Name & \begin{tabular}{|c|} 
Leaf \\
length \\
(LL)
\end{tabular} & $\begin{array}{l}\text { Leaf } \\
\text { width } \\
\text { (LW) }\end{array}$ & $\begin{array}{c}\text { Flag } \\
\text { leaf } \\
\text { length } \\
\text { (FLL) }\end{array}$ & $\begin{array}{c}\text { Flag } \\
\text { leaf } \\
\text { width } \\
\text { (FLW) }\end{array}$ & $\begin{array}{l}\text { Culm } \\
\text { length } \\
\text { (CL) }\end{array}$ & $\begin{array}{c}\text { Tiller } \\
\text { number } \\
\text { (TN) }\end{array}$ & $\begin{array}{l}\text { Culm } \\
\text { diameter } \\
\text { (CD) }\end{array}$ & $\begin{array}{l}\text { Panicle } \\
\text { length } \\
\text { (PL) }\end{array}$ & $\begin{array}{l}\text { Maturity } \\
\text { (MAT) }\end{array}$ & $\begin{array}{c}\text { Biomass } \\
\text { (BM) }\end{array}$ & $\begin{array}{c}\text { Harvest } \\
\text { index } \\
(\mathrm{HI})\end{array}$ & $\begin{array}{l}\text { Filled } \\
\text { grain } \\
\text { (FG) }\end{array}$ & $\begin{array}{l}\text { Grain } \\
\text { yield } \\
\text { (GY) }\end{array}$ \\
\hline Moroberekan & 42.54 & 15.17 & 35.29 & 16.00 & 56.00 & 2.67 & 3.60 & 19.34 & 144 & 5.22 & 0.09 & 23.65 & 0.48 \\
\hline Dular & 60.28 & 12.90 & 35.00 & 14.90 & 67.10 & 3.50 & 3.84 & 22.00 & 132 & 11.38 & 0.26 & 61.18 & 2.89 \\
\hline IR64 & 43.70 & 10.50 & 29.66 & 13.10 & 35.40 & 5.60 & 2.46 & 18.40 & 138 & 8.48 & 0.16 & 35.55 & 1.35 \\
\hline MR219 & 38.87 & 13.60 & 25.98 & 13.70 & 50.30 & 4.30 & 2.87 & 22.20 & 141 & 11.65 & 0.30 & 50.48 & 3.47 \\
\hline MR220 & 37.29 & 14.20 & 28.19 & 14.30 & 52.30 & 4.40 & 2.66 & 21.90 & 137 & 12.31 & 0.28 & 50.01 & 3.38 \\
\hline MR232 & 43.81 & 13.40 & 33.98 & 14.40 & 44.90 & 5.30 & 3.06 & 20.20 & 144 & 12.94 & 0.21 & 47.04 & 2.67 \\
\hline MR253 & 32.23 & 11.90 & 19.51 & 12.00 & 41.20 & 5.00 & 2.34 & 16.80 & 132 & 8.88 & 0.30 & 51.15 & 2.65 \\
\hline MR263 & 30.64 & 11.40 & 21.14 & 13.90 & 45.40 & 4.00 & 2.01 & 17.70 & 138 & 7.15 & 0.29 & 41.76 & 2.04 \\
\hline MR269 & 33.98 & 12.70 & 25.16 & 12.00 & 54.80 & 5.20 & 2.56 & 21.10 & 137 & 14.60 & 0.29 & 49.43 & 4.20 \\
\hline MRQ74 & 38.99 & 12.20 & 24.00 & 12.20 & 40.20 & 6.70 & 2.84 & 17.70 & 135 & 10.39 & 0.28 & 58.38 & 2.73 \\
\hline MRQ76 & 36.56 & 13.50 & 26.55 & 14.34 & 57.20 & 4.67 & 3.54 & 17.54 & 138 & 14.33 & 0.27 & 54.40 & 4.06 \\
\hline SIRAJ297 & 35.41 & 12.90 & 26.15 & 14.20 & 48.20 & 6.10 & 2.71 & 19.90 & 139 & 14.43 & 0.18 & 30.40 & 2.66 \\
\hline WANGI88 & 41.63 & 12.20 & 26.93 & 12.15 & 40.25 & 4.85 & 2.97 & 16.90 & 144 & 8.74 & 0.14 & 34.11 & 1.26 \\
\hline MARDI284 & 42.74 & 12.65 & 27.90 & 14.00 & 51.43 & 6.23 & 3.47 & 21.78 & 141 & 15.87 & 0.19 & 49.14 & 3.07 \\
\hline SEMPADAN303 & 42.42 & 13.50 & 35.96 & 13.60 & 50.90 & 4.70 & 2.69 & 22.10 & 137 & 11.21 & 0.21 & 38.75 & 2.37 \\
\hline SEBERNAS307 & 41.33 & 14.20 & 31.84 & 13.90 & 57.15 & 5.85 & 3.78 & 24.00 & 144 & 17.02 & 0.20 & 38.76 & 3.46 \\
\hline MARDI308 & 37.35 & 12.90 & 24.85 & 13.00 & 53.80 & 5.40 & 3.09 & 23.00 & 135 & 12.19 & 0.30 & 41.96 & 3.55 \\
\hline
\end{tabular}


Table.6 Mean comparison between two environments using Duncan's Multiple Range Tested

\begin{tabular}{|c|c|c|c|}
\hline \multirow{2}{*}{ Studied Traits } & \multicolumn{2}{|c|}{ Duncan's Multiple Range Test } & Percentage of reduction (\%) \\
\cline { 2 - 4 } & drought & control & \\
\hline Leaf length (LL) & 39.99 & 47.22 & 15.31 \\
\hline Leaf width (LW) & 12.93 & 13.24 & 2.34 \\
\hline Flag leaf length (FLL) & 28.12 & 32.07 & 12.32 \\
\hline Flag leaf width (FLW) & 13.63 & 15.34 & 30.64 \\
\hline Culm length (CL) & 49.80 & 71.80 & 28.77 \\
\hline Tiller number (TN) & 3.54 & 4.97 & 10.81 \\
\hline Culm diameter (CD) & 2.97 & 3.33 & 22.89 \\
\hline Panicle length (PL) & 20.15 & 26.13 & 17.08 \\
\hline Maturity (MAT) & 114.79 & 138.44 & 24.36 \\
\hline Biomass (BM) & 11.77 & 15.56 & 48.89 \\
\hline Harvest Index (HI) & 0.23 & 0.45 & 39.51 \\
\hline Filled Grain (FG) & 45.11 & 74.58 & 60.92 \\
\hline Grain yield (GY) & 2.79 & 7.14 & \\
\hline
\end{tabular}

Table.7 Major allele frequency, allele number, gene diversity, heterozygosity, and polymorphism information content (PIC) for 14 simple sequence markers (SSRs)

in 14 MARDI varieties

\begin{tabular}{|c|c|c|c|c|c|c|c|}
\hline $\begin{array}{c}\text { Chromosome } \\
\text { No. }\end{array}$ & $\boldsymbol{q D T Y}$ & Marker & $\begin{array}{c}\text { Major } \\
\text { Allele } \\
\text { Frequency }\end{array}$ & $\begin{array}{c}\text { Allele } \\
\text { No }\end{array}$ & $\begin{array}{c}\text { Gene } \\
\text { Diversity }\end{array}$ & Heterozygosity & PIC \\
\hline \multirow{2}{*}{$\mathbf{2}$} & 2.3 & RM530 & 0.512 & 6 & 0.668 & 0.023 & 0.628 \\
\hline \multirow{3}{*}{} & 3.2 & RM3894 & 0.946 & 2 & 0.101 & 0.012 & 0.096 \\
\cline { 2 - 8 } & 3.2 & RM6013 & 0.857 & 3 & 0.251 & 0.260 & 0.230 \\
\cline { 2 - 8 } & 3.2 & RM14291 & 0.674 & 5 & 0.516 & 0.011 & 0.488 \\
\hline \multirow{2}{*}{$\mathbf{6}$} & 6.1 & RM204 & 0.460 & 8 & 0.732 & 0.161 & 0.706 \\
\hline \multirow{3}{*}{11} & 6.1 & RM19367 & 0.561 & 5 & 0.565 & 0.167 & 0.384 \\
\hline & 6.1 & RM549 & 0.438 & 4 & 0.418 & 0.266 & 0.458 \\
\hline \multirow{2}{*}{12} & 11.1 & RM3625 & 0.768 & 4 & 0.375 & 0.083 & 0.332 \\
\hline & 11.1 & RM209 & 0.611 & 4 & 0.554 & 0.000 & 0.499 \\
\hline & 11.1 & RM7391 & 0.711 & 4 & 0.412 & 0.09 & 0.552 \\
\hline & 12.1 & RM573 & 0.573 & 4 & 0.528 & 0.188 & 0.442 \\
\hline & 12.1 & RM1261 & 0.622 & 3 & 0.248 & 0.218 & 0.284 \\
\hline & 12.1 & RM28099 & 0.587 & 5 & 0.588 & 0.308 & 0.506 \\
\hline & 12.1 & RM28166 & 0.418 & 4 & 0.482 & 0.214 & 0.468 \\
\hline
\end{tabular}


Fig.1 The graph shows the level of water table depth in five days at drought stress environment

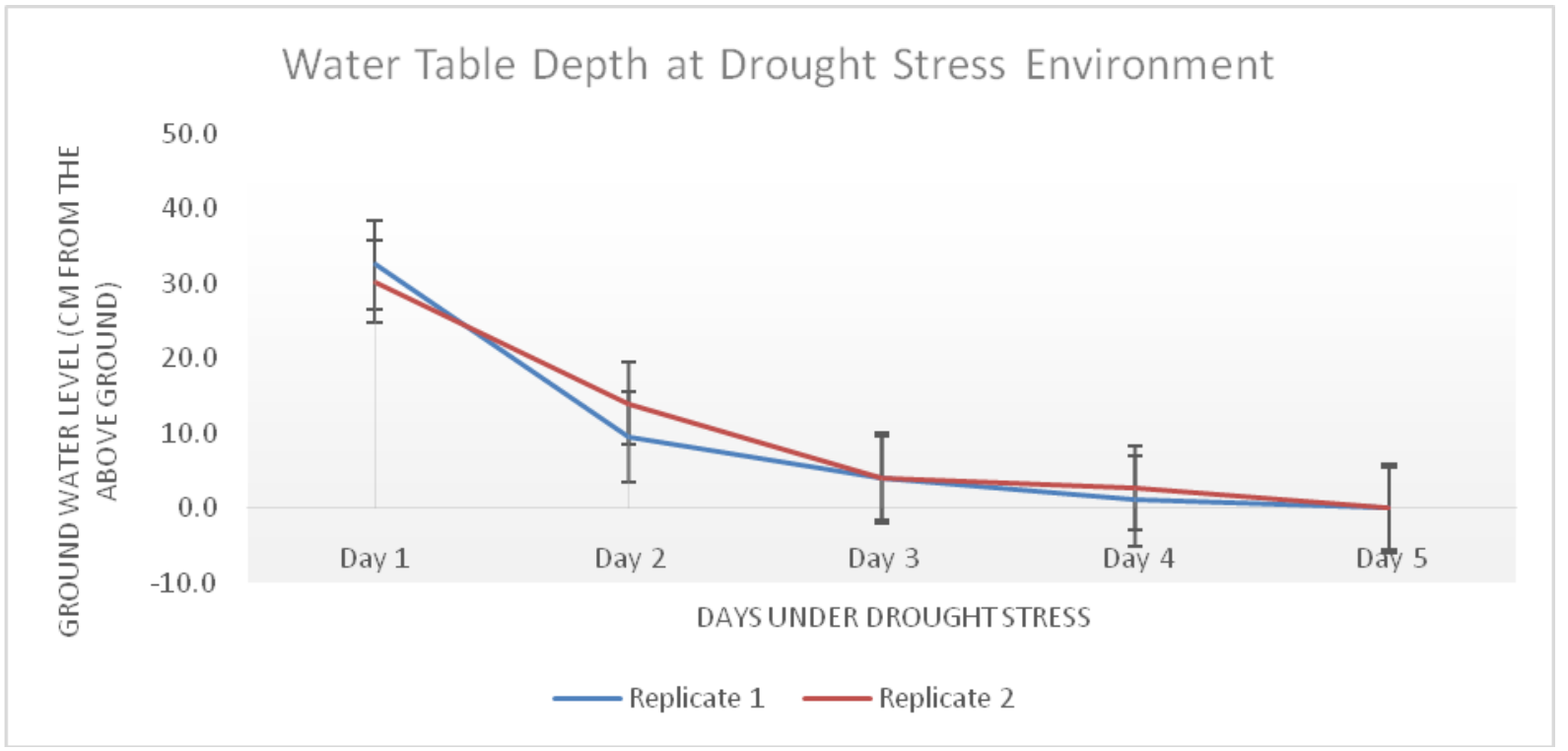

Fig.2 The graph shows the soil moisture under drought stress at day 26 and 33

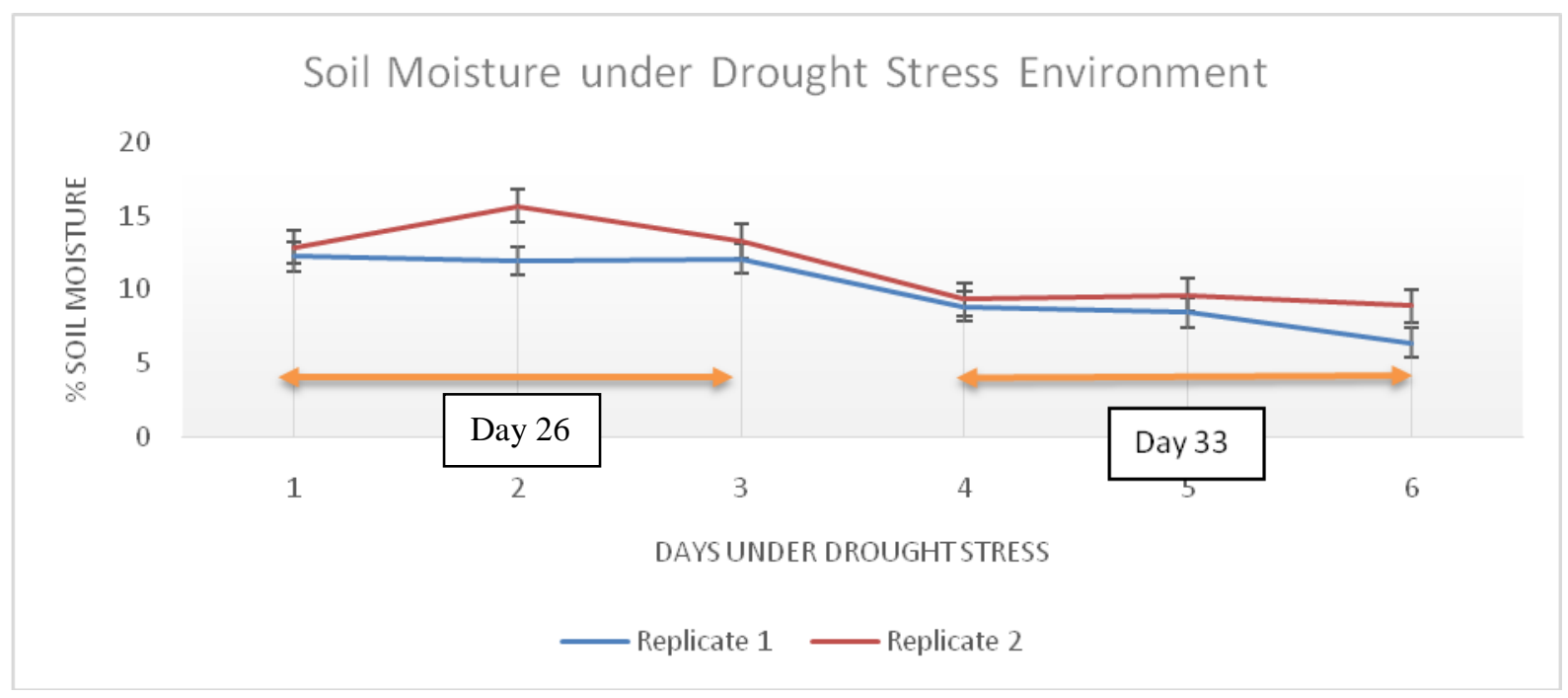


Fig.3 The grain yield of 14 MARDI rice varieties under drought stress environment.

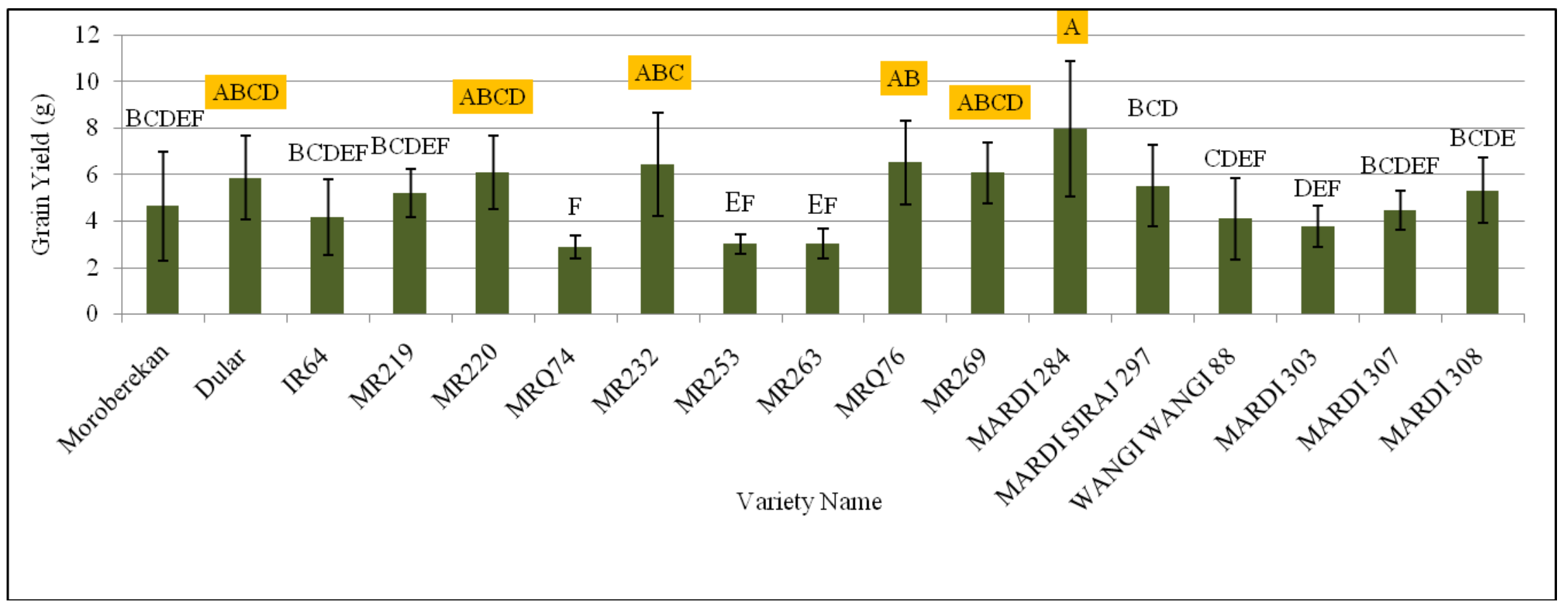


Fig.4 The least mean squares of grain yield under drought and control environments

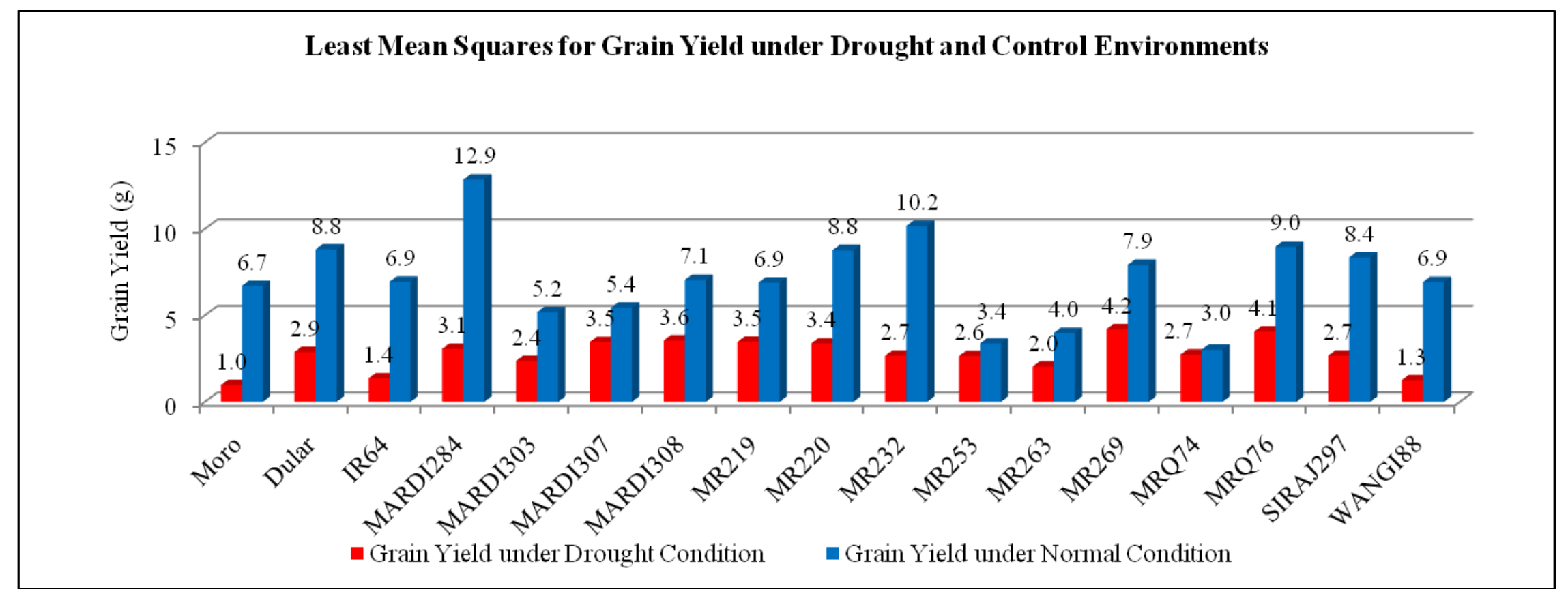


Fig.5 Frequency of SSR markers of each drought tolerance QTLs in MARDI varieties

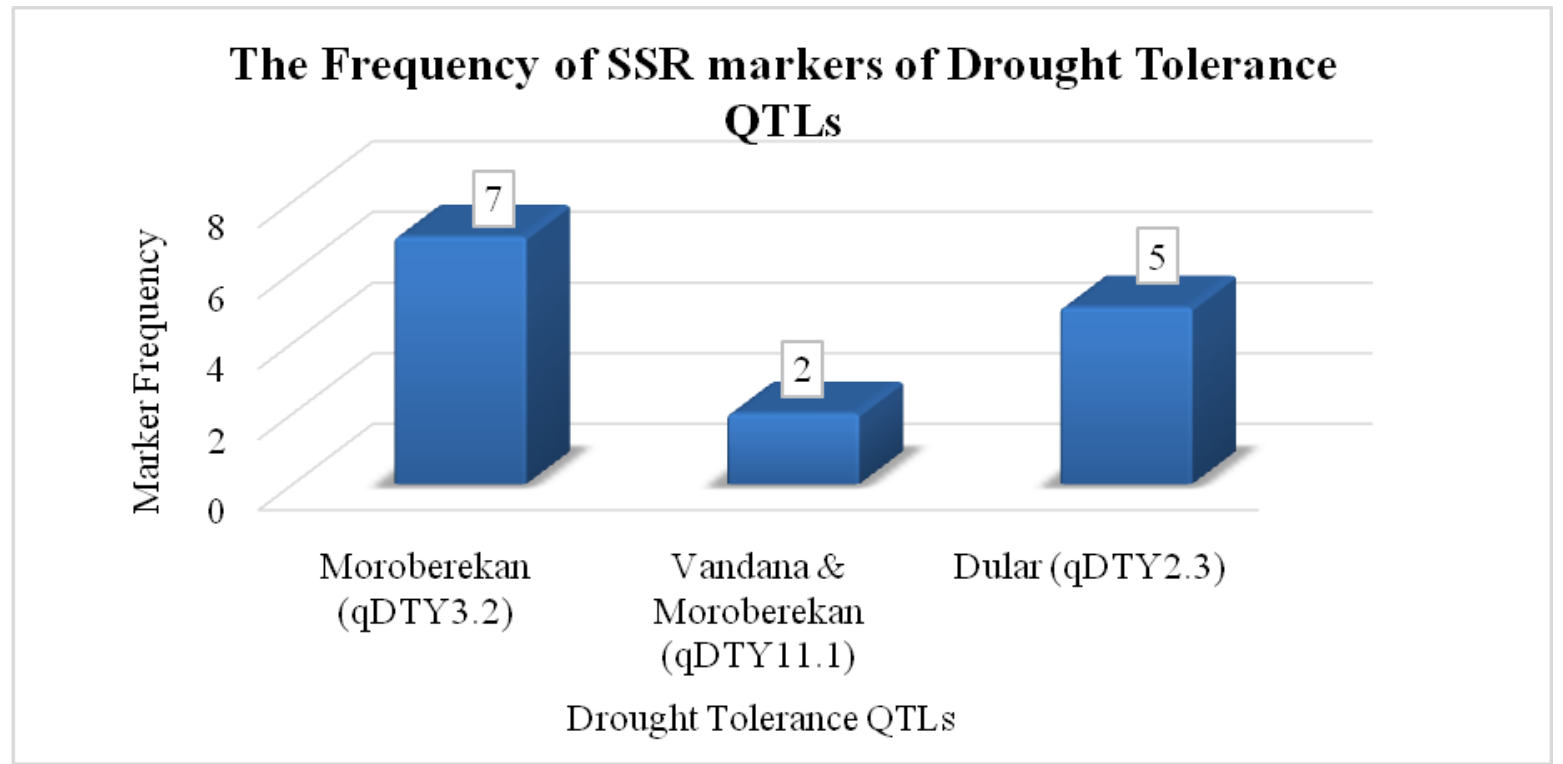

Fig.6 Dendrogram based on morpho-agronomic traits of fourteen MARDI rice varieties under drought stress environment

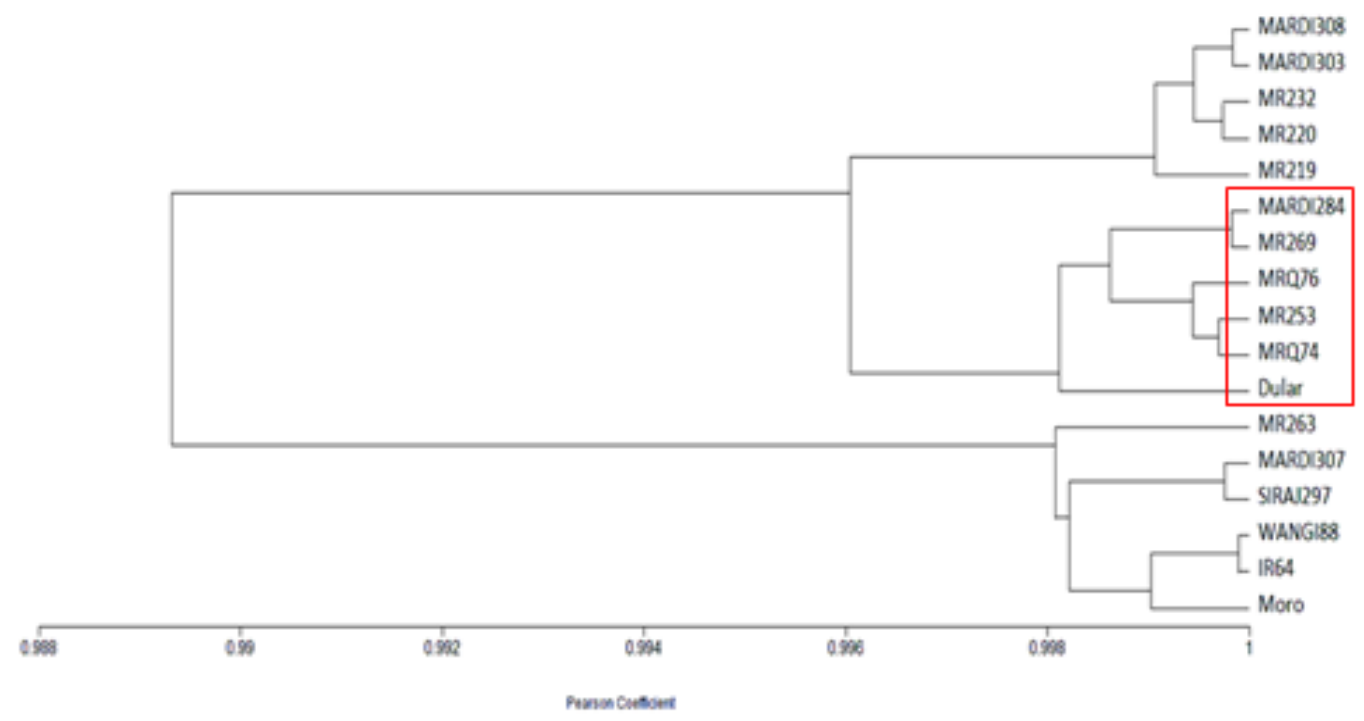


Fig.7 Dendrogram for fourteen MARDI varieties based on fourteen Simple Squence Repeat (SSR) markers linked to drought grain yield QTLs

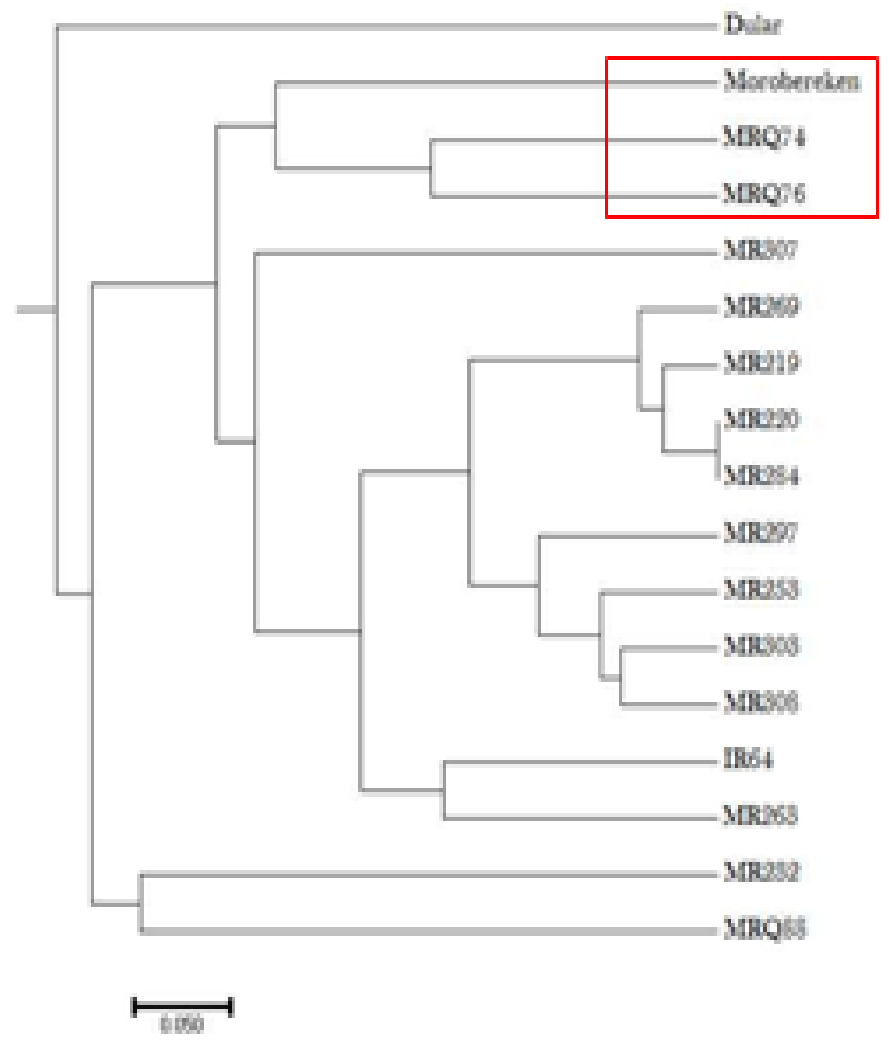

Picture.1 Rice plants under drought stress environment

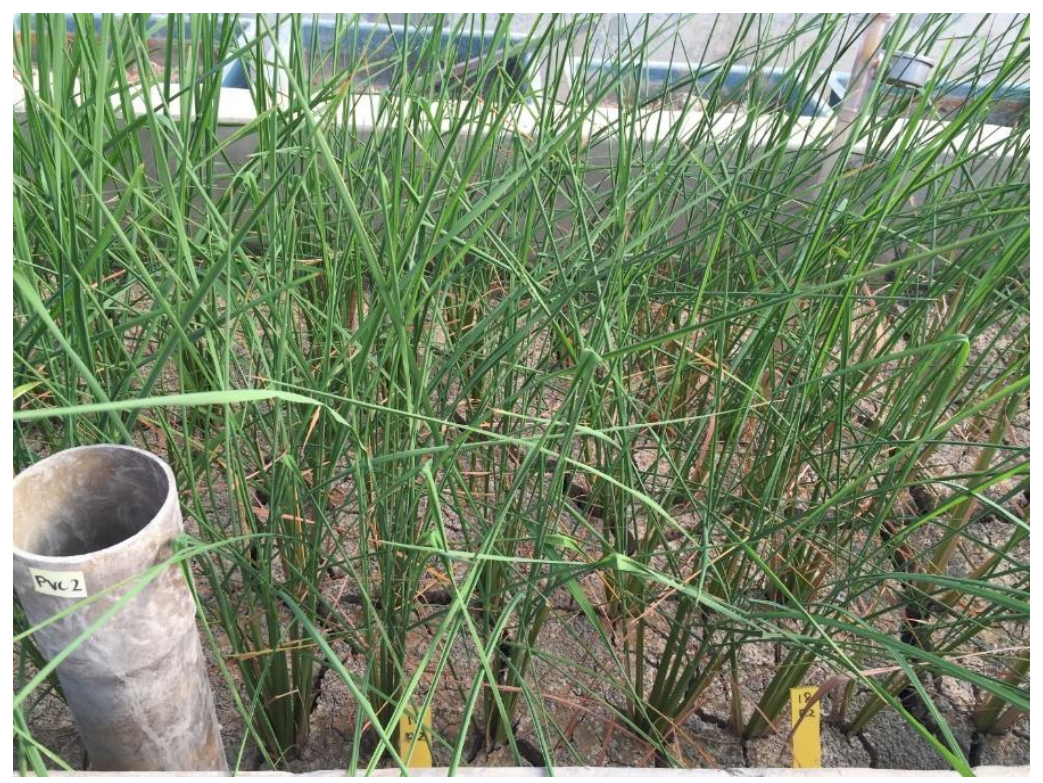


The marker also reported exhibit consistent effects on grain yield in two or more genetic backgrounds and ecosystems (Ghimire et al., 2012; Yadaw et al., 2013).

The second highest frequency of QTL was observed in $q D T Y_{2.3}$. The donor variety for this QTL is Dular. This QTL was amplified in five varieties, namely, MR253, MRQ76, SIRAJ297, WANGI88, and SEBERNAS307.This QTL had been reported had an effect on grain yield in cross multiple backgrounds (Kumar et al., 2014). Whereas, the lowest frequency of QTL was observed in $q D T Y_{11.1}$. The QTL was found in two MARDI rice varieties, namely, MRQ74 and

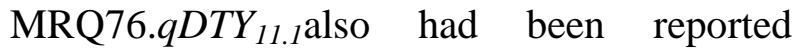
produce higher yield at reproductive stage under drought stress conditions (Sandhu et al., 2018).

This finding also discovered three MARDI rice varieties possess more than one QTLs. There wereMRQ74 possess $q D T Y_{3.2}$ and $q D T Y_{11.1} ; \quad$ MR253 possess $q D T Y_{2.3}$ and $q D T Y_{3.2}$; whereas MRQ76 possess $q D T Y_{3.2}$, $q D T Y_{2.3}$ and $q D T Y_{11.1}$. As stated by Swamy et al., (2011) the presence of at least one grain yield QTL will provide major effect in drought panel lines. Whereas, varieties with combinations of several QTLs allow more positive interactions between the different QTLs and provide more possibilities for breeders to capture a high yield advantage under reproductive-stage drought (Kumar et al., 2014).

\section{Identification of drought tolerant variety among MARDI rice varieties}

Two dendrograms for cluster analysis were constructed based on morpho-agronomic traits and genotypic traits using fourteen SSR markers linked to drought grain yield QTLs. Pearson's Correlation Coefficient used to measure statistical relationship based on morpho-agronomic traits divided MARDI rice varieties into three major groups(Figure 6). There are five MARDI rice varieties that were grouped together with Dular namely MARDI284, MR269, MRQ746, MR253, and MRQ74. While, genetic similarity coefficient based on genotypic traits showed most of the MARDI rice varieties were positioned into two major groups(Figure 7). Where, MRQ74 and MRQ76, were grouped together with Moroberekan.

MARDI284, MR269, MRQ76, MR253, and MRQ74which were grouped with Dular showed higher mean value in culm number, harvest index, $\%$ of filled grain, and grain yield. These varieties showed outstanding growth performance under drought environment almost similar to Dular. Three varieties, namely, MR269, MRQ76 and MARDI284 also showed no significant difference with Dular on grain yield under drought stress environment.

Based on the genotypic traits, MRQ74 and MRQ76 which were grouped together with Moroberekan were identified as carrier of more than one drought grain yield QTLs. $q D T Y_{3.2}$ and $q D T Y_{11.1}$ were identified in MRQ74, meanwhile $q D T Y_{3.2}, q D T Y_{2.3}$, and $q D T Y_{11.1}$ were identified in MRQ76. As an overall finding, the study showed thatMRQ76 is the prominent variety based on morphoagronomic traits and presence of QTLs under drought environment. The variety among the highest in GY production, FG, HI, less yield reduction difference under drought environment; and also possess three drought grain yield QTLs namely $q D T Y_{3.2}, q D T Y_{2.3}$, and $q D T Y_{11.1}$ that allowed the variety to perform well under drought stress environment.

Evaluation and assessment of genetic diversity in identifying the prominent MARDI rice variety that is suitable and adaptable to 
drought is considered as a primary step for designing effective breeding program in MARDI. This study reveals sufficient genetic diversity among the MARDI rice varieties and successfully identified MRQ76asthe most outstanding variety as exhibited great performance on morpho-agronomic traits (i.e., GY, FG, and HI, and yield reduction difference) under drought environment. In addition, MRQ76 was identified possess the highest numbers of grain yield QTLs compared to other MARDI rice varieties. The QTLs observed in MRQ76 were $q D T Y_{3.2}$, $q D T Y_{2.3}$, and $q D T Y_{11.1}$. This variety can be recommended for planting in drought prone areas and introduced as a promising donor variety for development of drought tolerant rice variety in MARDI.

\section{Acknowledgement}

Financial support through an R\&D grant under the $11^{\text {th }}$ Malaysia Project Plan is gratefully acknowledged. The authors would also like to thank all the staff at Rice Genebank, MARDI Seberang Perai, Pulau Pinangfor their support in this project.

\section{References}

Abd Allah, A. A., Ammar, M. H. and Badawi, A. T. (2010). Screening rice genotypes for drought resistance in Egypt. J. Plant Breeding and Crop Sci. 2(7): 205-215

Ahmad Jamalludin, S. and Low, K. S. (2003) Drought in Malaysia: A look at its characteristics, impacts related policies and management strategies. Water and Drainage 2003 Conference. 28-29 April 2003. Kuala Lumpur

Arif, I. A., Khan, H. A., Shobrak, M., Al Homaidan, A. A., Al Sadoon, M., Al Farhan, A. H. and Bahkali A. H. (2010). Interpretation of electrophoretograms of seven microsatellite loci to determine the genetic diversity of the AArabian Oryx. Genetics and Molecular Research 9(1):
259-265

Babu, R. C., Zhang, J. X., Blum, A., Ho, T. H. D., Wu, R. and Nguyen, H. T. (2004). HVA1, a LEA gene from barley confers dehydration tolerance in transgenic rice (Oryza sativa L.) via cell membrane protection. Plant Sci. 166: 855-862

Babu, R. C., Nguyen, B. D., Chamarerk, V., Shanmugasundaram, P., Chezhian, P., Jeyaprakash, P., Ganesh, S. K., Palchamy, A., Sadasivam, S., Sarkarung, S., Wade, L. J. and Nguyen, H. T. (2003). Genetic analysis of drought resistance in rice by molecular markers: Association between secondary traits and field performance. Crop Sci. 43: 1457-1469

Bernier, J., Kumar, A., Venuprasad, R., Spaner, D. and Atlin, G. N. (2007). A large-effect QTL for grain yield under reproductivestage drought stress in upland rice. CropSci.47: 507-516

Behera, L., Patra, B. C., Sahu, R. K., Nanda, A., Sahu, S. C., Patnaik, A., Rao, G. J. N., and Singh, O. N. 2012. Assessment of genetic diversity of rainfed rices using microsatellite markers. Aust J. Crop Sci. 6 (9): 1369-1376

Boonjung, H. and Fukai, S. (1996). Effect of soil water deficit at different growth stages on rice growth and yield under upland conditions: phenology, biomass production and yield. Field Crops Research 48: 47-55

Bueno, C. S. and Lafarge, T. (2009). Higher crop performance of rice hybrids than of elite inbreds in the tropics. 1. Hybrids accumulate more biomass during each phenological phase. Field Crops Research 112: 229-237

Che Khalija, I. M., Khairul H. M., and Siti Khalijah O. 2015. Impacts of natural disasters on the paddy production and its implications to the economy. FFTC Agricultural Policy Platform. https://ap.fftc.org.tw/article/970

Choudhary, G., Ranjitkumar, N., Surapaneni, M., Deborah, D. A., Vipparla, A., Anuradha, G., Siddiq, E. A., Vemireddy, L. R. 2013. Molecular genetic diversity of major Indian rice cultivars over decadal 
periods. PLoS One. 8(6): e66197

Condon, A. G., Richards, R. A., Rebetzke G. J. and Farquhar, G. D. (2004). Breeding for high water use efficiency. J. Exp. Bot. 55: $2447-2460$

DeWoody, J. A., Honeycutt, R. L. and Skow, L. C. (1995). Microsatellite markers in whitetailed deer. J. Hered. 86:317-319

Dixit, S., Singh, A., Sta Cruz, M. T., Maturan, P. T., AMante, M. and Kumar A. (2014). Multiple major QTL lead to stable yield performance of rice cultivars across varying drought intensities. BMC Genetics 15: 16

Fen, L. L., Mohd Razi, I., Zulkarami, B., Mohammad Shukri, A. R. and Robiul Islam, M. (2015). Physiological and molecular characterization of drought responses and screening of drought tolerant rice varieties. Bioscience Journal 31(3): 709-718

Fukai, S. and Cooper, M. (1995). Development of drought-resistant cultivars using physiomorphological traits in rice. Field Crops Res. 40: $67-86$

Ghimire, K. H., Quiatchon, L. A., Vikram, P., Mallikarjuna Swamy, B. P., Dixit, S., Ahmed, H., Hernandez, J. E., Borromeo T. H. and Kumar, A. (2012). Identification and mapping of a QTL $\left(q D T Y_{1.1}\right)$ with a consistent effect on grain yield under drought. Field Crops Research 131: 88-96

Inthanpan, P. and Fukai, S. (1988). Growth and yield of rice under sprinkler irrigation in south eastern Queensland, 2 -Comparison with maize ang grain sorghum under wet and dry conditions. Aust. J. Exp. Agric. 28: 243-338

Kamoshita, A., Chandra Babu, R., Manikanda Boopathi, N. and Fukai, S. (2008). Phenotypic and genotypic analysis of drought-resistance traits for development of rice cultivars adapted to rainfed environments. Field Crop Research 109: 123

Kumar, A., Dixit, S., Ram, T., Yadaw, R. B., Mishra K. K. and Mandal, N. P. (2014). Breeding high-yielding drought-tolerant rice: genetic variations and conventional and molecular approaches. J. Experimental
Botany 65(21): 6265-6278

Kumar, R., Venuprasad, R. and Atlin, G. N. (2007). Genetic analysis of rainfed lowland rice drought tolerance under naturallyoccurring stress in eastern India: heritability and QTL effects. Field Crop Research 103: $42-52$

Kumar, R. (2018). Development of drought resistance in rice. International J. Current Microbiology and Applied Sci. 7(5): 14391456

Kumar, S., Stecher, G. and Tamura, K. (2016). MEGA7: Molecular Evolutionary Genetics Analysis Version 7.0 for Bigger Datasets. Mol. Biol. Evol. 33(7):1870-1874

Kumar, S., Dwivedi, S. K., Haris, A. A., Prakash, V. E. D., Mondal, S. and Singh, S. K. (2015). Screening and identification of rice genotypes for drought tolerance at reproductive stage under rainfed lowland condition. J. AgriSearch 2(2): 105-111

Lanceras, J. C., Pantuwan, G. P., Jongdee, B. and Toojinda, T. (2004). Quantitative trait loci associated with drought tolerance at reproductive stage in rice. Pant Physiol. 135: 382-399

Li, Z. K., Fu, B. Y., Gao, Y. M., Xu, J. L., Ali, J., Lafitte, H. R., Jiang, Y. Z., Rey, J. D., Vijayakumar, C. H., Maghirang, R., Zheng, T. Q. and Zhu, L. H. (2005). Genome-wide introgression lines and their use in genetic and molecular dissection of complex phenotypes in rice (Oryza sativa L.). Plant Molecular Biology 59: 33-52

Mace, E. S., Buhariwalla, H. K. and Crouch, J. H. (2003). A high-throughput DNA extraction protocol for tropical molecular breeding program. Plant Molecular Biology Reporter 21: 459

Malaysian Meteorology Department. 2019. MET Annual Report 2019. Malaysian Meteorology Department. Selangor, Malaysia. 1-94

Marshall, C. (2007). World and Its Peoples: Eastern and Southern Asia. ISBN 978-07614-7642-9.Marshall Cavendish Corporation,99 White Plains Road, Tarrytown, New York 10591-9001

Gomez, M. S., Satheesh Kumar, S., Jeyaprakash, 
P., Suresh, R., Biji, K. R., Manikanda Boopathi, N., Adam, H. P. and Chandra Babu, R. (2006). Mapping QTLs linked to physio-morphological and plant production traits under drought stress in rice (Oryza sativa L.) in the target environment. American Journal of Biochemistry and Biotechnology 2(4): 161-169

Mishra K. K., Vikram, P., Yadaw, R. B., Swamy, B. P. M., Dixit, S., Sta Cruz, M. T., Maturan, P., Marker, S. and Kumar, A. (2013). $q D T Y_{12.1}$ : a locus with a consistent effect on grain yield under drought in rice. BMC Genetics 14: 12

Nachimuthu, V. V., Muthurajan, R., Duraialaguraja, S., Sivakami, R., Pandian, B. A., Panniao, G., Gunasekaran, K., Swaminathan, M., Suji, K. K., Sabariappan, R. 2015. Analysis of population structure and genetic diversity in rice germplasm using SSR markers: An initiative towards association mapping of agronomic traits in Oryza sativa. Rice. 8: 30

O'Toole, J. C. (1982). Adaptation of rice to drought prone environments. In:Drought Resistance in Crops with Emphasis on Rice. IRRI, Los Baños, Philippines. 195-213

Palanong, A. D., Swamy, M. B. P., Shamsudin, N. A. A., Dixit, S., Hernandez, J. E., Borromeo, T. H., Sta Cruz, P. C. and Kumar, A. (2014). Grain yield QTLs with consistent-effect under reproductive-stage drought stress in rice. Field Crops Res. 161: 46-54

Pantuwan, G., Fukai, S., Cooper, M., Rajasereekul, S. and O'Toole, J.C. (2002). Yield response of rice (Oryza sativa L.) genotypes to different types of drought under rainfed lowlands, Part 2. Selection of drought resistant genotypes. Field Crops Res. 73: $169-180$

Plaut, Z., Butow, B. J., Blumenthal, C. S. and Wrigley, C. W. (2004). Transport of dry matte into developing wheat kernels and its contribution to grain yield under postanthesis water deficit and elevated temperature. Field Crops Res. 86: 185-198

Radin Firdaus R. B., Tan M. L., Siti Rahyla R. and Senevi M. 2020. Paddy, rice and food security in Malaysia: a review of climate change impacts. Eds. Casadevall S. R. Cogent Social Science. 6 (1): 1-17. https://doi.org/10.1080/23311886.2020.181 8373

Ribaut, J. M., Bänziger, M., Setter, T., Edmeades, G. and Hoisington, D. (2004). Genetic dissection of drought tolerance in maize. A case study. In: Physiology and Biotechnology Integration for Plant Breeding (H. Nguyen and A. Blum (ed.). Marcel Dekker, Inc. New York

Roy, S., Banerjee, A., Mawkhlieng, B., Misral, A. K., Pattanayak, A., Harish, G. D., Singh, S. K., Nagchan, S. V. and Bansal, K. C. (2015). Genetic diversity and population structure in aromatic and quality rice (Oryza sativa L.) landraces from NorthEastern India. PLoS One. 10: e0129607

Sanchez, A. C., Subudhi, P. K., Rosenow, D. T. and Nguyen, H. T. (2002). Mapping QTLs associated with drought resistance in sorghum (Sorghum bicolor L. Moench). Plant Molecular Biology 48 (5-6): 713-726

Saw, S. H. (2007). The Population of Peninsular Malaysia. Institute of Southeast Asian Studies. ISBN 978-981-230-427-8.

Sandhu, N., Dixit, S., Swamy, B. P. M., Vikram, P., Venkateshwarlu, C., Catolos, M. and Kumar, A. (2018). Positive interactions of major-effect that enhances rice yield under drough. Scientific Reports 8: 16-26

Schuelke, M. (2002). An economic method for the fluorescent labeling of PCR fragments. Nature Biotechnology 18: 233-234

Singh, N., Choudhury, D. R., Tiwari, G., Singh, A. K., Kumar, S., Srinivasan, K., Tyagi, R. K., Sharma, A. D., Singh, N. K. and Singh, R. (2016). Genetic diversity trend in Indian rice varieties: An analysis using SSR markers. BMC Genet. 17:

Site Noorzuraini, A. R., Borromeo, T. H., Altoveros, N. C., Diaz, G. M. and Kumar, A. (2013). Diversity assessment of Malaysian rice germplasm accessions for drought tolerant grain yield QTLs. J. Trop. Agric. and Fd. Sc. 41(1): 27-40

Site Noorzuraini, A. R., Borromeo, T. H., Altoveros, N. C., Diaz, G. M. and Kumar, 
A. (2012).Growth performance of selected Malaysian rice germplasm under drought stress environment. J. Trop. Agric. and Fd. Sc. 40 (2): 169- 179

Siti Rahyla R. Radin Firdaus R. B. Samsurijan M. S. and Lim Y. L. 2019. Leading key players and support system in Malaysian paddy production chain. Eds. Yildiz F. Cogent Food \& Agriculture. 5 (1): 1-15. https://doi.org/10.1080/23311932.2019.170 8682

Swamy, B. P. M., Kaladhar, K., Ramesha, M. S., Viraktamath, B. C. and Sarla, N. (2011). Molecular mapping of QTLs for yield and related traits in Oryza sativa cv Swarna x $O$. nivara (IRGC81848) backcross population. RiceScience18 (3): 178-186

Vikram, P., Swamy B P. M., Dixit, S., Ahmed, H. U., Sta Cruz, M. T., Singh, A. K. and Kumar, A. (2011). $q D T Y_{1.1}$, a major QTL for rice grain yield under reproductive-stage drought stress with a consistent effect in multiple elite genetic backgrounds. $B M C$ Genetics 12(89): 1-15

Venuprasad, R., Bool, M. E., Quiatchon, L., Sta Cruz, M. T., Amante, M. and Atlin, G. N. (2012). A large effect QTL for rice grain yield under upland drought stress on chromosome. Molecular Breeding 30: 535547

Venuprasad,R., Dalid, C. O., Del Valle, M., Zhao, D., Espiritu, M., Sta Cruz, M. T., Amante, M., Kumar, A. and Atlin, G.N. (2009). Identification and characterization of large-effect quantitative trait loci for grain yield under lowland drought stress in rice using bulk-segregant analysis. Theoretical and Applied Genetics 120: 177190

Venuprasad, R., Lafitte, H. R., and Atlin, G. N. (2007). Response to direct selection for grain yield under drought stress in rice. Crop Science 47: 285-293

Vikram, P., Kadam, S., Singh, B. P., Lee, Y. J., Pal, J. K., Singh, S., Singh, O. N., Swamy, B. P. M., Thiyagarajan, K., Singh, S. and Singh, N. K. (2016). Genetic diversity analysis reveals importance of greem revolution gene ( $s d l$ locus) for drought tolerance in rice. Agricultural Research 5 (1): $1-12$

Wopereis, M. C. S., Kropff, M. J., Maligaya, A. R., Tuong, T. P. (1996). Drought-stress responses of two lowland rice cultivars to soil water status. Field Crops Res. 46: 2139.

Yang, J. and Zhang, J. (2010). Crop management techniques to enhance harvest index in rice. J. Experimental Botany. 61 (12): 3177-3189

Yadaw, R. B., Dixit, S., Raman, A., Mishra, K. K., Vikram, P., Swamy, B. P. M., Sta Cruz, M. T., Maturan, P. T., Pandey, M. and Kumar, A. (2013). A QTL for high grain yield under lowland drought in the background of popular rice grain Sabitri from Nepal. Field Crops Res. 144: 281-287

$\mathrm{Zu}, \mathrm{X}$., Lu, Y., Wang, Q., Chu, P., Miao, W., Wang, H., and La, H. 2017. A method for evaluating drought tolerance of upland rice cultivars. The Crop Journal. 5 (6):488-498 https://doi.org/10.1016/j.cj.2017.05.002.

\section{How to cite this article:}

Site Noorzuraini Binti Abd Rahman, Mohd Shahril Firdaus Bin Abd Razak, Norlida Mohamed Hamim, Mohd Ramdzan Bin Othman and Nur Idayu Binti Abd Rahim. 2021. Identification of Drought Tolerant among MARDI Rice Varieties based on Morpho-Agronomic Traits and Drought Grain Yield QTLs. Int.J.Curr.Microbiol.App.Sci. 10(08): 471-493. doi: https://doi.org/10.20546/ijcmas.2021.1008.058 